\title{
Measuring Policy Content on the U.S. Supreme Court
}

\author{
Kevin T. McGuire University of North Carolina at Chapel Hill \\ Georg Vanberg University of North Carolina at Chapel Hill \\ Charles E. Smith, Jr. University of Mississippi \\ Gregory A. Caldeira The Ohio State University
}

\begin{abstract}
Political scientists have developed increasingly sophisticated understandings of the influences on Supreme Court decision making. Yet, much less attention has been paid to empirical measures of the Court's ideological output. We develop a theory of the interactions between rational litigants, lower court judges, and Supreme Court justices. We argue that the most common measure of the Supreme Court's ideological output-whether the Court's decision is liberal or conservative - suffers from systematic bias. We trace this bias empirically and explain the undesirable consequences it has for empirical analyses of judicial behavior. Specifically, we show that, although the Court's preferences are positively correlated with the ideological direction of the justices' decision to reverse a lower court, the attitudes of the justices are negatively related - and significantly so - to the ideological direction of outcomes that affirm lower court decisions. We also offer a solution that allows scholars to work around this "affirmance bias."
\end{abstract}

$\mathrm{O}$ ver the last 50 years, political scientists and legal scholars have developed increasingly sophisticated models of judicial decision making, particularly for the U.S. Supreme Court. Scholars have demonstrated that a host of forces-including legal considerations (e.g., Richards and Kritzer 2002), the political preferences of justices (e.g., Rohde and Spaeth 1976; Schubert 1965; Segal and Spaeth 2002), strategic considerations arising from the relationships between the justices and between the Court and other policy makers (e.g., Epstein and Knight 1998; Eskridge 1991; Maltzman, Spriggs, and Wahlbeck 2000; Stearns 2002; Whittington 2005), and contextual factors such as organized interests and public opinion (e.g., Collins 2004; McGuire and Stimson 2005) - shape the outputs of the Supreme Court. Ironically, the measure of policy content utilized in such analyses has not been scrutinized as closely.

In studying the Court's outputs, scholars are typically interested in the rationale or rule that the Court offers to justify its judgment; after all, it is the justification that embodies the "policy content" of an opinion. Since this policy is encapsulated in lengthy prose and technical legal language, developing reliable and valid measures of "the law" created by the Court poses challenges. To deal with these difficulties, researchers have commonly used the ideological direction of the Court's judgment, liberal or conservative, as a proxy for the rationale of the decision, using the legal issue and the identity of the party that prevailed to assess whether the justices favored the liberal or conservative side in a dispute. In other words, the ideological tenor of the underlying rule (difficult to measure) has traditionally been approximated by the ideological direction of the judgment in the case (easier to measure). ${ }^{1}$

In this paper, we evaluate this measure critically. Central to our argument is that the ideological direction of the Court's judgment and the content of the underlying rule may, but need not, coincide. As we show in the next section, discrepancies between the ideological direction of the judgment in a decision and the ideological content of the opinion's rationale are not random but a predictable consequence

\footnotetext{
${ }^{1}$ This is the convention followed in the U.S. Supreme Court Judicial Database, which provides a series of protocols for coding the ideological direction of decisions. Although there can be disagreements about the ideological direction in some cases (Harvey 2006), one advantage of this approach is that it is considerably more reliable than trying to estimate the policy content of a decision.
}

The Journal of Politics, Vol. 71, No. 4, October 2009, Pp. 1305-1321

doi:10.1017/S0022381609990107 
of the strategic interactions among lower court judges, litigants, and Supreme Court justices. As a result, measures of the content of judicial decisions that rely on coding the direction of outcomes are likely to be biased in a systematic way. After presenting our theoretical argument, we demonstrate that this bias can be traced empirically, and that it has significant implications for the inferences that scholars draw in substantive research. We end by proposing a partial solution that continues to rely on the directional measure-a substantial advantage in light of the methodological difficulties involved in coding content-but significantly reduces bias and improves our ability to draw inferences.

\section{Strategic Litigants, Strategic Judges}

Since the earliest quantitative analyses of the Supreme Court, political scientists have assumed that the members of the Court vote according to their preferences in relation to the facts presented in each case. In the classic formulation, both the justices and the case facts are arrayed along a single ideological dimension, and whether a justice votes in a liberal or conservative direction is simply a function of her location relative to each case (Schubert 1965). A justice located to the right of a given case fact will vote conservatively; a justice to the left, liberally.

Our model of judicial decision making similarly assumes a one-dimensional "fact space" in which a case can be represented as a point, $x \in R$ (for recent similar approaches, see Carrubba et al. 2008; Lax and Cameron 2007). For example, the fact space in search and seizure cases might represent the intrusiveness of the search (with searches becoming more intrusive as we move to the right in the space), and the central question confronting the justices in any given case is whether a specific search violates the Fourth Amendment. Cases are then decided by the application of legal rules that determine which party ought to win for a given set of case facts. In this simple "case space" framework, legal rules are most easily represented by thresholds: Each rule marks out a threshold along the case-fact continuum such that case facts to the left of the threshold result in judgment for one party and those to the right result in judgment for the other party. To continue our example, consider Figure 1, which depicts the fact space for searches along a continuum. A legal rule, denoted by $x_{\mathrm{i}}$, indicates how intrusive a search may be before it becomes unconstitutional. Because the search at issue is located at $c$, - that is, to the right of this threshold-it is more intrusive than permitted by this legal rule. As a result, an opinion that adopts the rule $x_{i}$ would conclude that the search is unconstitutional.

The preferences of individual justices-whether induced by policy preferences or by legal considerations - are captured by the most preferred legal rule that a justice would like to see applied to a particular case. These legal rules become less attractive to a justice as they are further removed from her preferred legal rule. Thus, more conservative judges are motivated to pursue legal rules that allow for more intrusive searches; more liberal judges are likely to pursue legal rules that narrow the scope of intrusive searches. (We assume for the rest of our discussion that as legal rules move to the right in our fact space, they become more and more conservative. ${ }^{2}$ )

When drafting an opinion in a case, the Court expresses a particular legal rule. By doing so, the Court also resolves the dispute between the two parties, since the legal rule implies a judgment in favor of one party. On collegial courts, bargaining over the content of judicial opinions-that is, the legal rule-is obviously of central interest. For our purposes, however, we can remain agnostic on which justices are particularly influential in shaping opinion content. What is central for our argument is that opinions are characterized by a rule, which implies a judgment, and that political scientists have typically relied on the direction of the judgment as a proxy for the ideological content of the rule.

\section{The Supreme Court}

As Chief Justice Rehnquist explained, "[T]he most common reason members of our Court vote to grant certiorari is that they doubt the correctness of the decision of the lower court" $(1987,127)$, a view made manifest by the consistently high rate at which the Court has reversed the decisions of those lower courts whose decisions it reviews. To most political scientists who have studied the Court's agenda setting, the criterion by which the justices evaluate that correctness is ideological, as opposed to strictly legal (Boucher and Segal 1995). To be sure, in granting review to a lower court decision, the justices seek to

\footnotetext{
${ }^{2}$ This assumption implies that the "fact space" can be ordered in such a way that rules become more conservative as we move to the right. As long as there is general agreement on how to view the underlying issue (e.g., the intrusiveness of searches), this is an innocuous assumption.
} 


\section{Figure 1 Legal Rules in a Spatial Model}

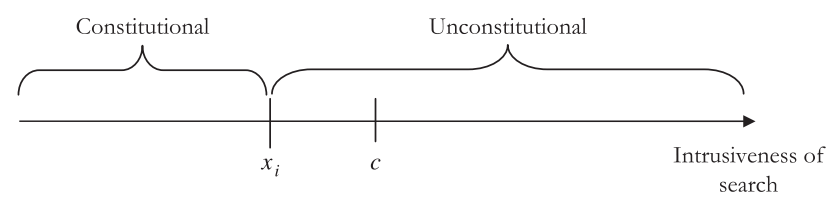

achieve other ends, as well: most notably, the Court seeks to resolve conflicts between lower courts (Ulmer 1984) and tries to fulfill an institutional obligation to address legal issues of national importance (Caldeira and Wright 1988). These agenda-setting objectives, however, are orthogonal to maximizing the justices' policy preferences at the merits (Perry 1991, 278). Thus, there is no reason-at least none of which we are aware-to believe that the Court's desire to ensure uniform legal policy on matters of national consequence is conditional on the justices' ideological goals; justices of all ideological stripes want to resolve conflict and address major policy questions.

Accordingly, we assume for the purposes of our argument that the Court's principal motive in selecting cases is to correct what is from its perspective an ideologically incorrect decision; that is, the justices grant cert because they believe that the legal rule adopted by the lower court represents a serious deviation from the legal rule that a majority of justices prefer (Supreme Court Assumption 1). We do not abstract away other agenda goals. Instead, we regard them as stochastic to an ideologically motivated process of case selection, a process that is the basis for our model.

A second salient feature of Supreme Court decision making is the presence of significant resource constraints. The justices can review only a small number of cases each term. Ceteris paribus, the Court is therefore more likely to grant plenary review to a lower court decision that deviates significantly from its preferred legal rule than one that more closely approximates it (Boucher and Segal 1995; Caldeira, Wright, and Zorn 1999; Supreme Court Assumption 2). In addition, the Court confronts informational constraints. When deciding whether to grant review to a case, the justices form an impression of the appropriateness of the rule embodied in the lower court decision. Their impression is usually accurate and (given our assumption about the Court's uniform interest in error-correction) results in the reversal of the lower court. On occasion, though, this impression turns out to be mistaken when the Court proceeds to decision making on the merits, in which case the justices end up affirming the lower court. So, on plenary review, the justices may discover that the lower court decision is on the correct side of the Supreme Court's preferred judgment rather than on the opposite side as initially perceived (Supreme Court Assumption 3). Finally, we assume that when deciding a case, the Court sets policy-expressed in a legal rule-at its most preferred point, i.e., at the rule threshold on which a majority of justices can agree (Supreme Court Assumption 4). Given the rule adopted by the Court, the justices also issue a judgment for the party that prevails under the rule. If the judgment favors the party that prevailed in the lower court, the justices affirm the lower court decision; if the other party wins, the justices reverse the lower court.

To illustrate, consider Figure 2. A lower court has issued a decision that establishes a legal rule at $D_{L C}$. Given the fact pattern $c$ in the case, this rule (and therefore the lower court decision) results in judgment in favor of one of the parties (say Party A). Suppose the losing party B favors a more conservative rule and appeals to the Supreme Court. If the Supreme Court perceives that $D_{L C}$ is a sufficiently serious deviation from its preferred rule, it will grant cert. In issuing its decision, the Court will move the legal rule rightward to its preferred legal rule, $X_{S C}$. Moreover, because the case facts fall below $X_{S C}$ (but fall above $D_{L C}$ ), the Court concludes that Party $\mathrm{B}$ - the petitioner-should have prevailed. Accordingly, it issues a reversal of the lower court decision.

\section{Lower Courts}

We assume that lower court judges have normally distributed preferences over legal rules and that they would like to write opinions that correspond as closely as possible to those preferred legal rules (Lower Court Assumption 1). At the same time, lower court judges act within a judicial hierarchy and, as such, are sensitive to the potential costs of being reversed by the Supreme Court. Among other things, reversals can damage the professional reputation of a judge and add to her workload if a case is remanded

\section{Figure 2 An Illustration}

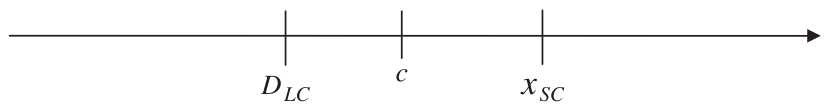


(Klein and Hume 2003). We therefore assume that, all things being equal, lower court judges prefer not to be reversed by the Supreme Court (Lower Court Assumption 2). Lower court judges therefore engage in a "balancing game"- they must trade-off their desire to issue decisions they prefer against the need to follow the Supreme Court to avoid reversal.

Of course, the exercise of this supervisory role is itself costly to the Supreme Court. So, we assume that lower court judges anticipate that they have some room, or "slack," to deviate from the Supreme Court's preferences without being reviewed (Cameron, Segal, and Songer 2000). Operating in an environment of uncertainty, lower court judges calculate this slack by estimating the distance between their preferences and those of the Court. They then exploit it to write opinions that more closely reflect their preferences, bearing in mind that greater deviations increase the likelihood of Supreme Court review (Lower Court Assumption 3). Naturally, lower court judges differ in the intensity of their preference for avoiding Supreme Court reversal, their estimate of the slack they have, and the value they place on seeing their own policy preferences implemented. Consequently, they vary in how boldly they will deviate from the Supreme Court's preferences (Lower Court Assumption 4).

Figure 3 illustrates these assumptions. Consider a lower court that prefers legal rule $X_{L C}$, far to the left of the Supreme Court's preferred rule of $X_{S C}$. Suppose the lower court either believes that it does not have much slack because the Supreme Court has abundant resources and is likely to take a case even if it deviates only slightly from the Court's preferred rationale, or it is so concerned about a reversal that it is unwilling to take a significant chance of review from the Supreme Court. In either case, the lower court will choose to stick closely to the Supreme Court's preferred rule, by issuing a lower court decision at, say, $D_{L C}$. If, instead, the lower court is bolder-because the threat of a reversal does not weigh heavily in its calculations or because it believes that the Court faces severe resource constraints that prevent it from reviewing even relatively significant deviations - it might issue a decision that deviates further, say, at $\tilde{D}_{L C}$.

\section{Figure 3 Lower Court Decision Making}

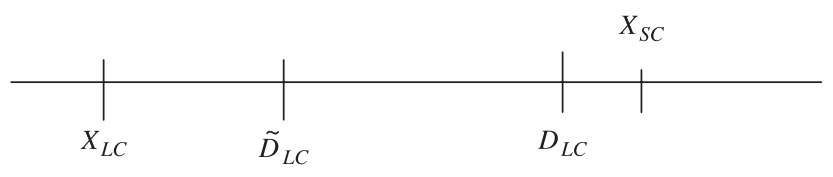

\section{Litigants}

In contemplating an appeal to the U.S. Supreme Court, potential petitioners consider both the costs of litigation and their probability of success (Songer, Cameron, and Segal 1995). We assume, therefore, that litigants petition for certiorari when they conclude that they are likely to succeed on the merits (Litigant Assumption 1). Thus, a litigant will appeal if she believes that the legal rule preferred by a majority of the Supreme Court is on the opposite side of the lower court judgment as applied to the case facts and will thus lead to a reversal of the lower court's judgment. $^{3}$

Figure 4 illustrates this assumption. Suppose a lower court has issued a decision at $D_{L C}$. The case facts are located at $c$, and the lower court has issued a judgment in favor of one party (say Party A). Party B, preferring a more conservative legal rule, appeals in the belief that the Supreme Court shares its policy orientations and prefers a legal rule at $X_{S C}$. Assuming Party B was correct in its estimate, the Court would grant cert and correct the lower court's error by setting policy at $X_{S C}$. In so doing, it would reverse what, from the litigant's perspective, is a liberal decision by the lower court, and the outcome could thus be classified as a "conservative reversal." On the other hand, suppose Party B believes that the Supreme Court's preferred rule is at $\tilde{X}_{S C}$. By this estimate, the Court is sympathetic to B's position in the sense that it also favors a more conservative legal rule than the one adopted by the lower court, but the Supreme Court-being to the left of the case facts-would still decide the case in favor of Party A. Party B estimates that it cannot secure a conservative reversal and therefore chooses not to appeal. (Assuming Party A has prevailed in the lower court, Party B would not appeal if it believed the Supreme Court's preferred rule to be to the left of $D_{L C}$.)

Note, however, that litigants make this decision under an informational constraint: while they have an estimate of where the Supreme Court would likely set policy $\left(X_{S C}\right)$, informed by its recent decisions,

${ }^{3}$ Ironically, of course, most petitions-indeed, as of this writing, at least $80 \%$ of petitions-do not satisfy our assumption: the in forma pauperis petitions are filed largely by the incarcerated, who for all obvious reasons consider neither the costs of litigating nor their likelihood of success. The Court has never regarded these cases as credible candidates for certiorari and, as a percentage of such cases filed, grants review to virtually none of them. Thus, like other studies of agenda setting and strategic litigation, we choose to ignore them (see, e.g., Caldeira and Wright 1988; Songer, Cameron, and Segal 1995). 
Figure 4 Litigant Decision Making

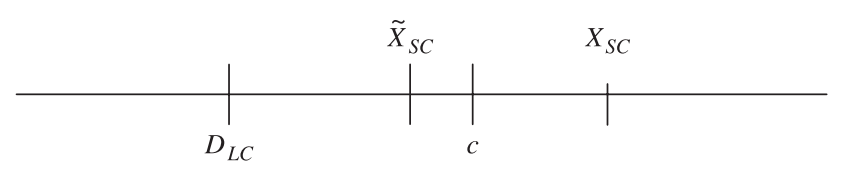

they cannot be sure about the Supreme Court's preferences. Litigants thus have a reasonable guess about the Court's preferences, but this guess is subject to error (Litigant Assumption 2). If, in Figure 4, Party B believes that the Supreme Court's preferred legal rule is quite conservative and located at $X_{S C}$, it will appeal. But, if the Supreme Court's preferred legal rule is, in fact, located at the less conservative $\tilde{X}_{S C}$, Party B will have estimated incorrectly and thus lose on the merits; the Supreme Court would affirm the lower court's decision. ${ }^{4}$ As we explain below, these incorrect estimates by litigants are crucial to our theory.

In choosing to appeal to the Supreme Court, there are different types of mistakes that a litigant can make. To see this, consider a petitioner who would benefit from a more conservative legal rule - that is, a petitioner who would like to secure a legal rule sufficiently to the right of the lower court decision to result in a reversal of the lower court's judgment. The petitioner believes that the case facts place the lower court ruling on the wrong side of the Supreme Court's preferred ruling and therefore appeals. What are the potential outcomes of this appeal? Figure 5 illustrates the possibilities. Suppose that (contrary to the petitioner's beliefs) $X_{S C}$-the Court's preferred rule-is located to the left of $D_{L C}$. If the Court grants cert and decides the case, it will issue a "liberal affirmance" by affirming the lower court decision against a petitioner who has argued in favor of a more conservative legal rule.

A second type of mistake occurs if $X_{S C}$ is located in the interval between $D_{L C}$ and $c$. In this case, depicted at the center of Figure 5, the petitioner has correctly perceived that the Supreme Court-like the petitioner-favors a more conservative legal rule than

\footnotetext{
${ }^{4} \mathrm{~A}$ reasonable question is why the Supreme Court would have taken the case for decision in the first place. Within our model, there are two possible reasons. First, the Supreme Court may perceive the difference between the legal rule established by the lower court and its own preferred rule to be sufficiently significant to take the case and move policy to $\tilde{X}_{S C}$, even if it agrees with the lower court on which party should prevail. Alternatively, the justices may have (erroneously) perceived that they disagreed with the lower court's disposition at the cert stage (see Supreme Court assumption 3).
}

the one embodied in the lower court decision. However, the petitioner has overestimated how conservative the Supreme Court is. Although the Court wants to move policy to the right, it is not so conservative as to arrive at a judgment different from that of the lower court-at least in terms of the party that should win the case. If the Court accepts such a case for plenary review, it will adopt a more conservative legal rule than the lower court, but the decisional outcome will be an affirmance of the lower court's judgment. As before, such an appeal would result in a "liberal affirmance." Importantly, this type of mistake is less severe than the first; the petitioner has at least correctly perceived the ideological direction of the Supreme Court's preferences relative to the lower court. He has merely overestimated the Court's level of conservatism. Because such a mistake is easier to make than the first, it should occur more frequently than the first.

Figure 6 illustrates the same dynamic for petitioners who would benefit from a more liberal legal rule than the one adopted by the lower court. The case facts $(c)$ must be located to the left of the lower court decision at $D_{L C}$ (otherwise, the petitioner could not benefit from a more liberal legal rule). Because she has chosen to appeal, the petitioner must believe that the Supreme Court favors a legal rule to the left of $c$. If she is correct, the Court issues a "liberal reversal." If the petitioner has estimated incorrectly, the Court issues a "conservative affirmance." Once again, mistakes in which the petitioner correctly estimates the direction of the Supreme Court's preferences but overestimates the Supreme Court's liberalness should be more frequent than mistakes in which the petitioner appeals to a Supreme Court that is more conservative than the lower court.

\section{Empirical Implications for the Ideological Content of Supreme Court "Output"}

Figures 5 and 6 illustrate four logically possible Supreme Court "outcomes" if the ideological content of a decision is coded from the direction of the Supreme Court's judgment (i.e., whether the Court favors the conservative or liberal side of a dispute): Conservative Reversals, Liberal Reversals, Conservative Affirmances, and Liberal Affirmances. Reversals occur when a petitioner correctly estimates the position of the Supreme Court, and affirmances result when the 


\section{Figure 5 Conservative Litigant Mistakes}

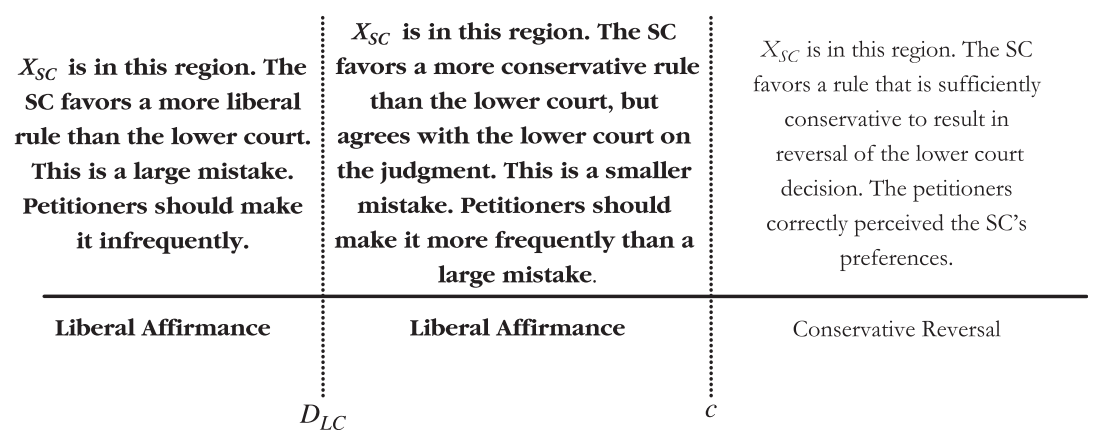

petitioner assesses the Supreme Court's position incorrectly. Are any of these outcomes more likely than the others? In light of our assumptions, we can draw several general conclusions.

\section{Implication 1: Petitioners should win significantly} more often than they lose.

Since petitioners are likely to have a reasonable estimate of the Court's ideological location, we expect that their estimate of the Court's position is more often correct than it is mistaken. Moreover, in granting cert, the justices are primarily motivated by a desire to "correct" lower court errors; that is, they are more likely to grant cert to a petition challenging a lower court decision they are inclined to reverse. Thus, the "pool" of cases from which the justices select cases to decide on the merits is biased towards cases in which the Court is likely to reverse.

Implication 2: When petitioners lose, it is more likely that they have overestimated the intensity of Supreme Court preferences than that they have miscalculated the direction of the Court's preferences.

When the Supreme Court affirms a lower court decision, it is because the petitioner has made a "mistake"; she has brought the case to the Court on the incorrect impression that the Supreme Court prefers a judgment in her favor to the lower court's decision. As we outlined above, there are two ways in which such mistakes can occur. One possibility is that, although the petitioner correctly estimates that the Court agrees with her on the direction in which the legal rule ought to be moved (e.g., both believe that more intrusive searches should be permissible under the Fourth Amendment), she does not realize that the Court's preferences are not sufficiently intense to result in a reversal (e.g., the petitioner believes that highly intrusive searches should be permitted, while the Court favors only moderately intrusive searches).

The other error petitioners can make is to believe that the Supreme Court's preferred legal rule is located on the same side of a case fact as the petitioner relative to the lower court, when the Court's preferred legal rule is on the opposite side. Under such circumstances, the Court is inclined to move legal policy in precisely the opposite direction of that preferred by the petitioner. For instance, suppose that the petitioner believes the Court favors permitting highly intrusive searches, when in fact it favors placing severe restrictions on intrusive searches. Under this scenario, the petitioner has not only misidentified the intensity of

\section{Figure 6 Liberal Litigant Mistakes}

\begin{tabular}{c:c:c}
$\begin{array}{c}X_{S C} \text { is in this region. The SC } \\
\text { fin this region. The SC } \\
\text { favors a rule that is sufficiently } \\
\text { liberal to result in reversal of } \\
\text { the lower court decision. The } \\
\text { the lower court, but agrees } \\
\text { petitioners correctly perceived } \\
\text { the SC's preferences. }\end{array}$ & $\begin{array}{c}X_{S C} \text { is in this region. The SC } \\
\text { judgment. This is a smaller } \\
\text { fastake. Petitioners should } \\
\text { make it more frequently than a more conservative } \\
\text { large mistake. }\end{array}$ & $\begin{array}{c}\text { This is a large mistake. } \\
\text { Petitioners should make it } \\
\text { infrequently. }\end{array}$ \\
\hline Liberal Reversal & Conservative Affirmance & Conservative Affirmance
\end{tabular}


the Court's preferences, but the direction: while the petitioner believed that the Court prefers a more conservative policy, the Court actually prefers a more liberal one.

Although the latter cases can and do arise, we believe that they should be rare, because they require the most serious errors in judgment on the part of the petitioner. Such cases require the petitioner to misunderstand not simply how conservative or liberal the Supreme Court is. Instead, the petitioner must completely misunderstand the ideological direction in which the Court would prefer to move legal policy. We expect these "larger" mistakes to occur much less frequently than the "small" ones. In other words, cases in which the petitioner has mistaken the direction in which the Court would like to move legal policy should constitute only a small fraction of the Court's plenary docket.

The exact degree of the litigants' accuracy-that is, the precise frequencies with which they make correct v. incorrect estimates-does not figure in our model. For our purposes, we need only assume that, regardless of whether they prefer to move legal policy to the left or to the right, litigants have the same information, the same ability to formulate an estimate of the Supreme Court's location, and the same likelihood, on average, of petitioning the Court in light of such considerations. Given these general expectations, we can now consider subtler influences on the balance of types of decisions issued as the Supreme Court's ideology changes over time.

A Centrist Supreme Court. Suppose the Supreme Court occupies a centrist position (i.e., a majority of justices would prefer to adopt legal rules that fall close to the center of the preference distribution of the lower courts). ${ }^{5}$ Given our assumptions (and the assumption that lower-court preferences are approximately normally distributed), lower court decisions should fall in roughly equal number and at similar distances to the right and to the left of the Supreme Court. As illustrated in Figure 7, some lower courts will be bolder in their deviations from the Supreme Court's preferred policy; others, more timid. Given that the distribution of lower court preferences is

${ }^{5}$ While it is possible to think about the ideological position of a political actor in reference to some absolute scale, it typically makes more sense to think of preferences in relation to the political context. Thus, a "conservative" Supreme Court is conservative precisely because it is more conservative than most other actors in the political system. In discussing Supreme Court ideology, we thus consider the Court's ideology relative to the ideological distribution of lower courts. symmetric about the Supreme Court's position at $X_{\mathrm{SC}}$, these deviations should be roughly equal on either side of the Court's preferred rule. Lower court decisions that fall to the right will tend to be appealed by petitioners who favor a more liberal legal rule and lower court decisions that fall to the left will tend to be appealed by petitioners who favor a more conservative legal rule. In general, both types of petitioners will be "accurate" about the Supreme Court's preferences most of the time. Some, of course, will make mistakes, but there is no reason to think that one group or the other will be more susceptible to making such errors.

What would we see if we were to look at the aggregate composition of the Court's opinions as measured by the direction of the Court's decisions? Overall, there should be more reversals than affirmances (see Implication 1). Because roughly an equal number of lower court decisions fall to the right and the left of the Supreme Court's preferred policy, we expect a rough balance of "liberal" and "conservative" reversals (see Figure 5 and Figure 6). Among affirmances, we should see the same pattern: because liberal and conservative petitioners make mistakes at roughly the same rate, we expect to observe about the same number of "liberal" affirmances as "conservative" affirmances. The aggregate consequence of these outcomes should be an approximate ideological balance across the types of decisions issued by the Court: there should be about as many "conservative" as "liberal" decisions, which, after all, is what one would expect from a centrist Supreme Court.

A Conservative Supreme Court. Now, suppose that, through the replacement of one or more justices, the Supreme Court becomes more conservative relative to lower courts (i.e., in Figure 7, the Supreme Court's most preferred legal rule moves to the right relative to the distribution of lower court preferences). A critical consequence of this movement is that a preponderance of lower court decisions will now be located to the Supreme Court's left. This is true because, given our assumptions, lower courts are

\section{Figure 7 Position of Supreme Court Relative to Lower Courts}

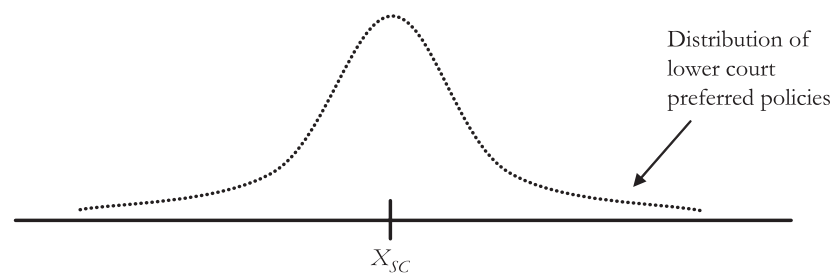


likely to take note of the Supreme Court's "shift" and adjust their decisions by "following" the Court to the right. But, they do so only to the extent they perceive necessary in order to avoid Supreme Court reversal. Because most lower courts will now prefer legal rules that are more liberal than those preferred by the newly conservative Supreme Court, these courts will exploit whatever "slack" they believe they have to issue decisions that deviate to the left of the Supreme Court's preferred policy. Lower courts to the right of the Court, by contrast, have less need to deviate, since the Court's shift in preferences has brought the Court closer to their own preferences. Because these deviations are greater to the left of the Court than to the right, petitioners who would benefit from a more conservative legal rule have a greater chance of securing review from the Court and prevailing on the merits. Thus, petitions seeking conservative policies will predominate for two reasons: There are more lower court decisions to the Court's left than to its right, and these decisions are more likely to be granted cert by the Supreme Court.

Regardless of whether they seek conservative or liberal legal rules, rational petitioners generally "guess right" about the Supreme Court's own preferred standard and thereby secure reversals. Because petitioners seeking conservative policy outcomes (i.e., the cases represented by Figure 5) now command a larger share of the Court's plenary docket than those seeking liberal legal change (i.e., the cases represented by Figure 6), the number of conservative reversals increases relative to the number of liberal reversals. So, as the Court has moved to the right, the ideological composition of the Court's output as measured by reversals also shifts in a conservative direction, exactly as one would expect; a more conservative Court produces a larger number of conservative reversals than liberal reversals.

Now consider cases in which petitioners have made a mistake, those in which the Court affirms the lower court's decision. Because most of the significant deviations from the Court's preferred rule-that is, the cases the Court is mostly likely to review-are located to the left of the Court, petitioners who challenge those deviations will be responsible for a larger share of "correct guesses" (i.e., conservative reversals) and a larger share of "incorrect guesses" (i.e., liberal affirmances). This implies that liberal affirmances will outweigh conservative affirmances. Ironically, a more conservative Court will produce more liberal affirmances than conservative affirmances.

Because reversals are more common than affirmances, as the Supreme Court shifts to the right, the ideological direction of its decisions-taken in the aggregate-is likely to reflect a shift in a conservative direction; most of the Court's decisions will be reversals, and most of those reversals will be conservative. But this aggregation hides an important twist: although a shift to the right by the Court leads to an increase in the number of conservative decisions among reversals, the exact opposite is likely to be true in cases in which the Court affirms; as the Court shifts to the right, the number of liberal affirmances begins to outpace the number of conservative affirmances.

\section{Case Direction versus Opinion Content}

The central implication of the foregoing argument is that the common directional measure of Supreme Court outputs will be misleading when applied to decisions to affirm. The reason is that, although litigants who wish to move policy in the same direction preferred by the Court will appeal more often and offer the Court more credible cases for certiorari, they will be responsible for larger shares of both reversals (which should reflect the Court's preferences) and affirmances (which should run contrary to them).

As we demonstrate in the next section, this conclusion has significant implications for the conventional directional measure of Supreme Court outputs. Our evidence indicates that any aggregate ideological measure that combines affirmances and reversals merges two sets of case outcomes that move in decidedly different ideological directions. Thus, including affirmances - which, as we show, run increasingly counter to the true underlying ideological position of the Court as it moves towards one or the other end of the ideological spectrum relative to the lower courts-introduces systematic bias in this measure.

\section{Empirical Support}

If our argument is correct, a counterintuitive empirical implication follows:

Implication: As the Supreme Court moves to the right relative to the lower courts, its output as measured by the ideological direction of decisions will become more conservative in reversals and more liberal in affirmances. Conversely, as the Court moves left relative to the lower courts, its output as measured by the ideological direction of decisions 
will become more liberal in reversals and more conservative in affirmances.

In this section, we offer evidence in support of this implication. Using data from the U.S. Supreme Court Judicial Database, we examine annual liberalism in terms of outputs, differentiating between reversals and affirmances. We expect reversals to reflect changes in the Court's preferences over time and affirmances to run counter to them. Testing our expectation-which depends on the preferences of the Supreme Court relative to the lower courtsrequires a measure of the relative ideological distance between the Supreme Court and the lower courts. Just how liberal or conservative is the Supreme Court compared to lower courts? Generating data on the preferences of the members of the Supreme Court has long been problematic, and finding comparable data for lower court judges is an even more difficult task. While sophisticated measures of the justices' preferences have been developed (e.g., Martin and Quinn 2002), these typically do not allow us to compare across the Supreme Court and lower courts.

To deal with this difficulty, we construct a measure of the preferences of the Supreme Court relative to the lower courts by focusing on a proxy that has the advantage of being available for both the Supreme Court and the Courts of Appeals: the party affiliation of the judges' appointing president. We measure the relative preferences of the Supreme Court as the difference in the percentage of Supreme Court justices and Court of Appeals judges appointed by Democratic presidents. The larger this difference, the more liberal the Supreme Court, relative to the lower courts. ${ }^{6}$ In an ideal world, of course, we would have similar estimates for judges on state courts. Unfortunately, federalism frustrates such an effort, ${ }^{7}$ and we therefore focus on cases in which the

\footnotetext{
${ }^{6} \mathrm{We}$ use this measure because it provides an estimate of relative preferences on which our argument focuses. It is worth noting, however, that the Supreme Court's absolute preferences could be used in lieu of relative preferences. After all, although the partisan composition of the both Supreme Court and Courts of Appeals should be correlated over time, the much larger number of federal appellate judges ensures that Court of Appeals preferences will not move as dramatically in ideological space over time as those of the Supreme Court. So, these relative preferences are likely to correlate with absolute preferences. Indeed, conducting our analysis with such a measure-we use the widely adopted Segal-Cover (1989) scores-yields substantively similar results. These results appear in the appendix.

${ }^{7}$ There are important variations in the selection mechanisms for the judges on state supreme courts. Thus, although a great many state judges do serve under a party label, a substantial number do not.
}

Supreme Court reviewed the decision of a federal appellate court.

\section{Aggregate Analysis}

Figure 8 provides a rough first cut at our implication: it plots our measure of relative Supreme Court preferences, and the annual liberalism of Supreme Court outputs, broken down by reversals and affirmances. ${ }^{8}$ These data confirm our theoretical expectations; the two time series for reversals and affirmances clearly run counter to one another. ${ }^{9}$ Both are measures of annual liberalism, differing only by whether the Court reversed or affirmed the lower court, and yet they are negatively correlated $(r=$ $-.42, \mathrm{p}<.002)$. Moreover, as expected, the series for reversals closely follows the measure of how liberal the Court is relative to lower courts: when the Court moves rightward relative to the courts of appeals, its outputs are more conservative, while a Court that is more liberal than its lower court counterparts generates more liberal policy $(r=.79, \mathrm{p}<.001)$. By contrast, the comparable series for affirmances reveals the opposite trend; although it is counterintuitive to observe a more conservative Court producing more liberal policy outcomes $(r=-.42, \mathrm{p}<.002)$, it is precisely what our theory predicts.

Although Figure 8 is suggestive, we can be more systematic in evaluating the implication of our argument. Our theory implies that, as the Supreme Court moves relative to the lower courts, the Court's outputs in reversals will reflect the Court's preferences, and the output in affirmances will run counter to them. Thus, our measure of Supreme Court's preferences should correctly predict the ideological direction of the Court's output in reversals, but it should have a negative relationship with the ideology of outputs in affirmances. Table 1 reports these results. For each OLS model, the dependent variable is the

\footnotetext{
${ }^{8}$ To classify outcomes as reversals or affirmances, we rely upon the "WIN" variable in the U.S. Supreme Court Judicial Database. This variable measures which party prevailed, the petitioner or the respondent, and it may generally be interpreted as a simplified version of the "DIS" variable, which takes account of the Court's specific order (e.g., affirm, reverse, vacate and remand, affirmed in part and reversed in part, dismissed).

${ }^{9}$ To underscore visually the important variation, we smooth each time series to a uniformly weighted moving average, calculated using the values for two previous terms, the current term, and three future terms. We then center them by standardizing each to a mean of zero and standard deviation of one. Note, though, that the correlation coefficients we report are derived from the original, unsmoothed series.
} 


\section{Figure 8 Relative Supreme Court Preferences and Supreme Court Liberalism in Reverals and Affirmances}

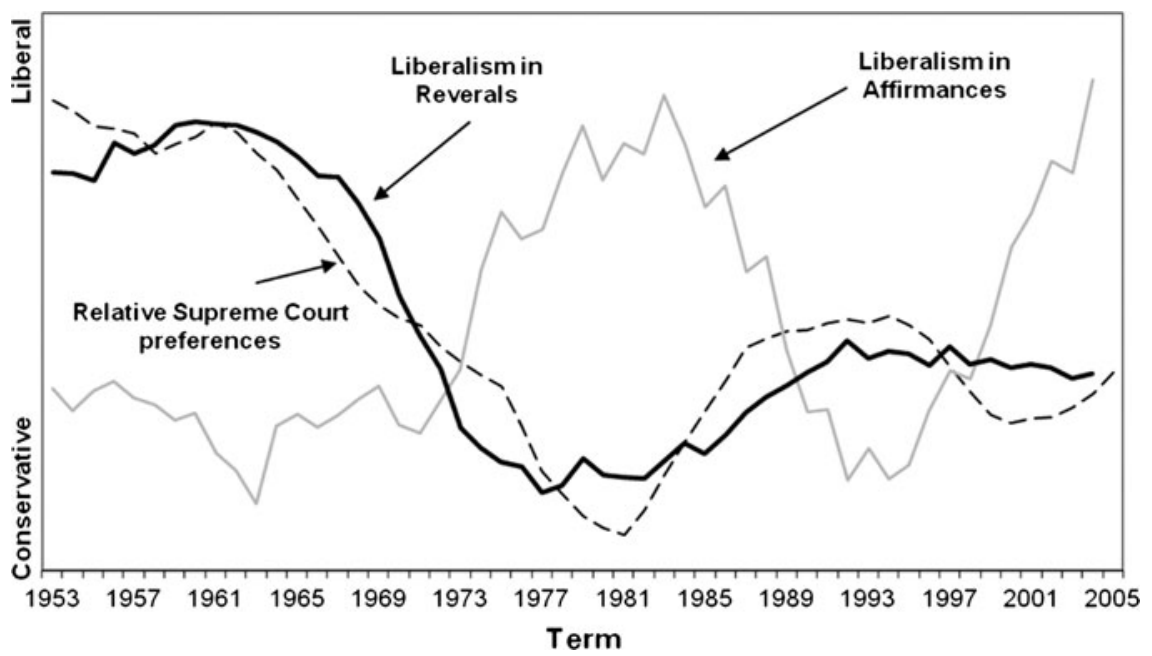

annual percentage of cases decided in a liberal direction. ${ }^{10}$

Our independent variable is the Supreme Court's preferences, measured as the Court's ideology relative to the ideology of the federal appellate courts. (To check the robustness of our results, we also test our models utilizing a conventional measure of the Court's preferences-the Segal-Cover [1989] scores-and these results are presented and discussed in the appendix.) In addition, we include a lag of the dependent variable as a corrective for first-order autocorrelation. We employ three different versions of the dependent variable-liberalism as measured by reversals, affirmances, and both types of cases combined.

Model 1, which relies on the standard construction of the dependent variable, combines reversals and affirmances in measuring the ideological direction of the Court's outputs. As expected, the distance between justices' preferences and those of the lower courts is a strong predictor of the Court's liberalism. Though the magnitude of this variable's impact and its substantive interpretation are interesting in their own right, this coefficient and the model from which it is derived are for us a useful baseline against which to evaluate other specifications. ${ }^{11}$

\footnotetext{
${ }^{10}$ The unit of analysis is docket number, including split votes, for all orally argued cases from the federal courts of appeals decided by full opinion for the 1953-2004 Terms.

${ }^{11}$ Readers interested in the magnitude of the effect of the Court's preferences and how it varies between models will find the appendix especially useful.
}

Model 2 represents the first test of our theory, measuring liberalism as captured by reversals only. As expected, the coefficient for the ideological distance between the justices and lower-court judges is positive. Indeed, the estimate associated with this variable is almost twice as large after affirmances are jettisoned, increasing from .52 in the first equation to .87 in the second. If we shift our focus to affirmances, we should observe a contrary result, and Model 4 confirms this expectation. The coefficient for the preference measure for the Supreme Court is significant and negative. For affirmances, the measure suggests that as the Court moves in a conservative direction, it generates more liberal policy decisionsclearly a nonsensical result.

Models 3 and 5 provide an additional robustness check. Some accounts of Supreme Court decision making suggest that the decision to affirm might be a by-product of having to resolve conflicts among the lower courts (see, e.g., Segal and Spaeth 2002, 262-65). If the justices grant certiorari to cases that present conflict because of their institutional responsibility to unify federal law, not necessarily as a means of advancing their policy goals, then the cases that involve conflict among lower courts may undercut our observation of the "error correction" strategy that is assumed by our model. So, if we eliminate these cases from our analysis, the estimates for the Court's policy preferences should become larger in both equations. Accordingly, we recalculated our annual time series for reversals and affirmances, excluding all cases in which the majority opinion 
TABLE 1 Models of Annual Liberalism on the Supreme Court, 1953-2004

\begin{tabular}{|c|c|c|c|c|c|}
\hline \multirow[b]{2}{*}{ Variable } & \multirow{2}{*}{$\begin{array}{c}\text { All Cases } \\
(1)\end{array}$} & \multicolumn{2}{|c|}{ Reversals Only } & \multicolumn{2}{|c|}{ Affirmances Only } \\
\hline & & $\begin{array}{l}\text { All Cases } \\
\text { (2) }\end{array}$ & $\begin{array}{c}\text { Conflict excluded } \\
\text { (3) }\end{array}$ & $\begin{array}{c}\text { All Cases } \\
(4)\end{array}$ & $\begin{array}{c}\text { Conflict excluded } \\
\text { (5) }\end{array}$ \\
\hline $\begin{array}{l}\text { Supreme Court } \\
\text { Preferences }\end{array}$ & $.52^{\star}(.13)$ & $.87^{\star}(.18)$ & $.94^{\star}(.21)$ & $-.44^{\star}(.15)$ & $-.81^{\star}(.21)$ \\
\hline Dynamics $\left(\mathrm{Y}_{\mathrm{t}-1}\right)$ & $.23(.13)$ & $.35^{\star}(.12)$ & $.35^{\star}(.12)$ & $.01(.14)$ & $-.02(.14)$ \\
\hline Constant & $.48(.08)$ & $.49(.09)$ & $.48(.09)$ & $.40(.06)$ & $.34(.06)$ \\
\hline R-Squared & .51 & .74 & .68 & .18 & .30 \\
\hline
\end{tabular}

Note: $N=51$. Dependent variable is the annual percentage of cases decided in a liberal direction. The Supreme Court's Preferences are relative preferences, measured as the percentage of Supreme Court justices appointed by a Democratic president minus that same percentage for judges on the U.S. Courts of Appeals. These same models, using the Court's absolute preferences appear in the appendix. Numbers in parentheses are standard errors; ${ }^{\star} \mathrm{p}<.01$.

cited some type of conflict as a reason for granting review. $^{12}$ As expected, excluding cases involving conflict enhances the predictive power of both models and the size of their coefficients, especially in the model for affirmances. Indeed, the coefficient for the justices' preferences increases from -.44 to -.81 , an almost two-fold increase in the estimate for that variable from the first affirmance equation. Reversals also evince a healthy improvement, increasing from .87 to .94 , when conflict cases are excluded. (Note, though, that any such comparisons between models must necessarily be made with caution, since the dependent variable is different in each equation.)

In short, our analysis of the Court's aggregate outputs provides powerful evidence consistent with our argument. The preferences of the Court are reflected in the Court's outputs when we consider reversals; but affirmances run counter to the Court's preferences, as the Court diverges more and more from the lower courts. Thus, including affirmances in a measure of the ideological direction of the Court's outputs introduces systematic bias.

\footnotetext{
${ }^{12}$ So, for example, we exclude all cases where, according to the Supreme Court Database, the Court's reasons for granting certiorari included such considerations as conflict between or among circuits and confusion or uncertainty among federal or state courts. Prior to Congress eliminating virtually all appeals in 1988, cases that came to the Court via the writ of appeal were, in theory at least, nondiscretionary. The Court, however, has long treated appeals as discretionary (Perry 1991). So, we include them in our aggregate calculations. Because the Supreme Court Database does not take account of the reason for granting review in appeals, though, we cannot say which appeals present conflict. We therefore exclude them from our calculations for the time series in which there was no conflict. This choice has no invidious implications for any of our inferences, however. Our results look substantially the same when appeals are included.
}

\section{Moving to the Individual Level}

Although our argument is aimed at measures of the ideological content of Supreme Court decisions, it also has implications for the voting behavior of individual justices. After all, both lower courts and litigants make decisions based upon their estimate of the Supreme Court's "preferred legal rule" and that estimate is derived from observations and beliefs about its individual members. Thus, the dynamics we identify for the Court as a whole should be present in the voting behavior of justices whose preferences are close to the policies that the Court as a whole is likely to adopt. The justices who are most likely to reflect the Court's preferred legal rule are at the ideological center of the Court. Since these justices so often control the outcomes of cases, their preferences on any given issue are thus a proxy for the legal rule preferred by the Court. Lower courts should adjust their policies in light of the ideological center of the Court. Likewise, the tendency for litigants to "guess right"-as well as make mistakes_regarding the Court's preferences should be keyed to the centrist justices. As a result, the pattern we observe at the aggregate level should be present in their voting records; votes to reverse should track their ideology; votes to affirm should run counter to them.

In contrast, the same is not true of justices on the ideological wings of the Court. Whatever that level of uncertainty when estimating the Court's (i.e., the centrist justices') preferred legal rule, it is becomes progressively less the farther a justice is from the Court's center. Stated differently, regardless of whether they vote to reverse or to affirm the lower court, the justices at either end of the ideological spectrum will 
vote in ways that reflect their ideology. For that reason, it does not matter whether a litigant is correct in estimating that the Court will move legal policy, say, to the right in a given case, since the most conservative justices will still likely vote conservatively (i.e., to reverse), just as the most liberal justices will still likely vote liberally (i.e., to affirm); that is, we expect little divergence between the two types of votes. This line of argument thus yields a testable implication:

Implication: For justices close to the center of the Court, liberalism as measured by the direction of individual votes to reverse should track a justice's ideology. Liberalism as measured by votes to affirm should run counter to the justice's ideology. For justices located away from the Court's center, liberalism as measured by individual votes to reverse and votes to affirm should track a justice's ideology equally well, especially for justices located at the Court's extremes.

To test this hypothesis, for each term from 1953 to 2004, we first rank-order the justices by their ideological distance from the Court's median justice (as measured by Segal-Cover scores). We then separate the justices into three, roughly equal-sized groups. The three justices closest to the center of the Court (Group 1), the three justices at intermediate distance from the center (Group 2), and the three justices who are furthest from the median (Group 3). ${ }^{13}$ Our hypothesis leads us to expect that for justices in Group 1, ideology correctly predicts liberalism as measured by votes to reverse, but that liberalism in votes to affirm will run counter to ideology. For justices in Group 2, ideology will correctly predict liberalism in votes to reverse. For votes to affirm, ideology will either run counter to liberalism in votes, or it will predict liberalism poorly. Finally, for justices in Group 3, the difference between liberalism in votes to affirm and votes to reverse should vanish-ideology will predict liberalism equally well for each type of vote. Table 2 presents these results.

The results are clear. Consider the center group of justices first. When we restrict attention to liberalism as measured in votes to reverse, liberalism

\footnotetext{
${ }^{13}$ Because there are occasionally "ties" in the distance from the median of different justices, it is not possible to achieve a perfectly even division-justices at the same distance must be assigned to the same group. However, the results we report below are robust to different methods of breaking this tie (i.e., assigning all to the lower category, or assigning all to the higher category). The results are also robust to a specification that uses continuous distance from the median and interacts that measure with the justices' preferences.
}

tracks ideology well. As justices become more liberal according to their Segal-Cover scores, their rate of liberalism increases significantly. The picture changes dramatically in votes to affirm; the estimated coefficient is negative and significant. For justices in the center of the court, their voting behavior appears to become more conservative as the justice becomes more liberal-a result that follows directly from our argument. Now consider the group of justices located at an intermediate distance from the Court's center. As expected for these justices, liberalism in votes to reverse tracks ideology well. But for votes to affirm, there is virtually no relationship between the justice's ideology and the measured ideological content of their votes; the estimated coefficient is close to zero and insignificant, and the R-squared of the regression is negligible. Finally, consider the justices at furthest remove from the Court's center. For these justices, there is little distinction between liberalism in votes to affirm and votes to reverse.

These individual level results provide unambiguous support for our argument. ${ }^{14}$ For justices at the extremes of the Court, ideology predicts the justices' votes, regardless of whether they happen to be votes to reverse or votes to affirm. However, as we move towards the center of the Court-the gravitational force for lower courts and the strategic target for petitioning litigants - the ideology of the justices begins to run counter to the ideological direction of their voting behavior as measured in votes to affirm. Just as in the aggregate results, it is evident that the inclusion of votes to affirm-for the theoretical reasons outlined above-introduces systematic bias into the simple, directional measure of the ideological output of judicial decisions.

\section{An Analytic Prescription}

To this point, we have documented the marked differences that manifest themselves in ideological measures of the Court's (and justices') output when we disaggregate decisions into decisions that (and votes to) reverse and affirm lower court decisions. These differences-not previously contemplated by scholars of the Court-are dramatic, revealing that the ideological direction of decisions to reverse

\footnotetext{
${ }^{14}$ Because Segal-Cover scores are exogenous to the voting record of justices on the Court, we prefer this measure of ideology for the current analysis. However, substantively similar results emerge if we use Martin-Quinn scores to conduct the analysis.
} 
TABle 2 Annual Liberalism of Justices by Distance from Center, 1953-2004

\begin{tabular}{|c|c|c|c|c|c|c|}
\hline \multirow[b]{2}{*}{ Variable } & \multicolumn{2}{|c|}{ Center Justices (Group 1) } & \multicolumn{2}{|c|}{ Intermediate Justices (Group 2) } & \multicolumn{2}{|c|}{ Extreme Justices (Group 3) } \\
\hline & $\begin{array}{l}\text { Votes to } \\
\text { Reverse }\end{array}$ & $\begin{array}{l}\text { Votes to } \\
\text { Affirm }\end{array}$ & $\begin{array}{l}\text { Votes to } \\
\text { Reverse }\end{array}$ & $\begin{array}{l}\text { Votes to } \\
\text { Affirm }\end{array}$ & $\begin{array}{l}\text { Votes to } \\
\text { Reverse }\end{array}$ & $\begin{array}{l}\text { Votes to } \\
\text { Affirm }\end{array}$ \\
\hline $\begin{array}{l}\text { Segal-Cover } \\
\text { Score }\end{array}$ & $.73^{\star}(.09)$ & $-.33^{\star}(.13)$ & $.62^{\star}(.08)$ & $-.03(.08)$ & $.28^{\star}(.07)$ & $.44^{\star}(.08)$ \\
\hline Constant & $.22(.05)$ & $.68(.07)$ & $.22(.06)$ & $.45(.06)$ & $.39(.06)$ & $.25(.05)$ \\
\hline R-Squared & .58 & .14 & .56 & .00 & .22 & .39 \\
\hline $\mathrm{N}$ & 166 & 166 & 151 & 151 & 152 & 152 \\
\hline
\end{tabular}

Note: Distance from the center is measured as the absolute value of each justice's deviation from the median justice's Segal/Cover score. Dependent variables are the annual percentage of liberal votes in votes to affirm and the annual percentage of liberal votes in votes to reverse, based on federal cert cases involving no conflict. Numbers in parentheses are robust standard errors, clustered by justice; ${ }^{*} \mathrm{p}<.05$.

conforms to our expectations about the linkage between ideology and behavior and that the direction of decisions to affirm runs counter to them. What, then, is the corrective? Our recommendation is that analyses of the Supreme Court that use the direction of the Court's decision as a proxy for the ideological position of an opinion should rely upon decisions (or votes) to reverse as the appropriate set of decisions (or votes) from which to generalize. We should note that this is a corrective that is independent of other transformations and indeed should precede these. For example, in an influential article, Baum (1988) developed a method for correcting for changes in the content of the Court's docket over time. To do so, he examined the median change in liberal voting for the justices who served from one term to the next and attributed such change to the different character of the cases on the docket at different points in time (i.e., that cases were becoming "harder" or "easier" to decide in a liberal direction.) Because this method relies upon votes to affirm as well as votes to reverse, it necessarily includes data that we believe frustrate attempts to gauge the content of the Court's caseload and the policies that emanate from it. Moreover, Baum was specifically interested in comparing changes in liberalism over time. As we have shown, however, the inclusion of votes to affirm contaminates cross-sectional inferences, as well. Thus, our recommended corrective has more general implications that transcend analyses such as those undertaken by Baum. Any analysis that includes the ideological direction of votes or decisions to affirm relies upon invalid indicators.

Because it surely seems strange to suggest that scholars should "throw out"-or at least "treat separately" - a large number of decisions, it is important to be clear about the nature of our claim. We are not claiming that decisions in which the Court affirms a lower court are unaffected by ideological considerations. Nor are we saying that the content of opinions in those cases cannot be meaningfully placed in ideological space. Rather, our claim is conditional. If the ideological direction of the Supreme Court's decision is taken as a proxy for the ideological content of the decision-an approach that is widespread among judicial scholars-then affirmances should be excluded because they are likely to introduce systematic bias into this particular proxy measure. Indeed, we suspect that prior research has succeeded in connecting the Court's preferences to votes despite this systematic bias only because votes to reverse are simply more common than votes to affirm and thus overwhelm the distorting influence of including affirmances.

It is easiest to illustrate the potential significance of this prescription for statistical inferences through an example. To do so, we revisit the enduring controversy over the impact of public opinion on decisions of the U.S. Supreme Court. Although a number of scholarly studies have investigated this linkage, one of the most important is a debate published in 1994 in the American Political Science Review. The previous year, William Mishler and Reginald Sheehan (1993) reported evidence of the Court's responsiveness to public preferences. Skeptical of this result, Helmut Norpoth and Jeffrey Segal (1994) observed that these scholars had not taken account of the dramatic realignment in the Court's preferences that occurred between the liberal Warren Court and the conservative Burger Court. Moreover, Norpoth and Segal noted, when Mishler and Sheehan did control for the Court's preferences, they had assessed the impact of the Court's ideological composition from the previous year, rather than its 
composition at the time of its decisions. By taking into account the large Warren-to-Burger shift or by controlling for the Court's preferences at the time of the justices' decisions, Norpoth and Segal demonstrated that the direct effect of public opinion disappeared.

Our aim here is not to reopen this debate; we do not challenge the results of Norpoth and Segal. Instead, we simply explore what they might have found had our analytic prescription been employed in their analysis. In replicating their results, we rely upon the same variables calculated over the same time period, 1956-89, and estimate the models with identical procedures. (We do make one alteration. In their exchange, Norpoth and Segal differed with Mishler and Sheehan as to how long it might take the justices to respond to changes in public preferences. Stated empirically, the issue was whether-and to what degree-the measure of public opinion should be lagged in statistical models. Rather than try to resolve this issue, we construct what we think is the most strenuous test of public opinion's effect by requiring the contemporaneous impact of public opinion to compete with the Court's preferences for explanatory power. ${ }^{15}$ )

We begin by reestimating the two equations most central to their analysis. ${ }^{16}$ The first models the Court's annual liberalism as a function of current public mood and the pronounced shift in the Court's policy orientation brought about by the Nixon appointees. The second replaces the Warren Court/ Burger-Rehnquist Courts dummy variable with a more continuous measure of the justices' preferences, the sum of the justices' ideological scores as measured by Segal and Cover (1989). These results appear in the first two columns of Table 3. This exercise confirms the findings of Norpoth and Segal; the relevant coefficients are more or less indistinguishable from those that they reported, and the story they impart is same: the Court's preferences determine the

\footnotetext{
${ }^{15}$ According to Norpoth and Segal, who doubt the effects of public opinion, no matter how many lags of public opinion are employed, the justices would always have to evaluate past opinion relative to current opinion, and thus, if public opinion matters, the analyst should always find evidence of its contemporaneous effects $(1994,712)$.

${ }^{16}$ We are grateful to William Mishler for providing us with a copy of their original data. These same data were also used by Norpoth and Segal in their analysis. To facilitate comparison to our alternative models, we recalculated their measure of annual liberalism and then calculated a comparable series after dropping all the decisions to affirm the lower court. There is nothing invidious in our reestimation of the original time series; indeed, our measure of this series is virtually identical to Mishler and Sheehan's $(r=.97)$.
}

direction of the Court's aggregate policymaking and public opinion does not.

Next, we vary their specification only by eliminating affirmances from our estimate of the Court's annual liberalism. By calculating the Court's policy outputs by what we regard as the more valid indicator (i.e., reversals), a very different empirical picture emerges. According to the results in the third and fourth columns in Table 3, not only does public opinion exercise a statistically significant effect, but the impact of the Court's preferences also increases. By eliminating the distortion introduced by including affirmances, we uncover a clear linkage between public mood and the justices' policies. At the same time, the increase in the coefficients measuring the Court's attitudes confirms that there are no trade-offs between the Court's and the public's preferences; not only does the effect of public opinion increase in our alternative models, but the justices' policy orientations likewise have an even more pronounced connection to the Court's decision making.

Seen in this way, we have not crafted a strategy to maximize the impact of one variable at the expense of another. Rather, by relying upon a more valid indicator of the Court's policies, we can better illuminate the underlying impact of a variety of competing explanations. That our modeling strategy provides such clarity on an issue that has generated so much disagreement is, we think, a strong test of our theory.

\section{Implications and Conclusions}

Empirical measures of the ideological content of Supreme Court outputs are central to much of the scholarly work on judicial behavior and on the interactions between the Supreme Court and the other parts of the political system. The most commonly used measure makes use of the direction of the Court's judgment - that is, whether the "liberal" or "conservative" side in a dispute prevails-as a proxy for the ideological content of the underlying policy output or rule of a decision. The ideological content of the Court's output or of a particular justice's voting record can then be estimated by the proportion of liberal (or conservative) decisions. Here, we have developed a theoretical argument that suggests that this conventional measure suffers from a systematic bias that can confuse inferences about the Court's decision making. Specifically, as the Supreme Court's preferences change relative to the preferences of 
Table 3 “Popular Influence on Supreme Court Decisions" American Political Science Review (1994), Replication and Corrected Models

\begin{tabular}{lcccc}
\hline Variable & \multicolumn{2}{c}{ Replication Models (all cases) } & \multicolumn{2}{c}{ Corrected Models (reversals only) } \\
\hline Public Mood $(t)$ & $.22(.27)$ & $.23(.32)$ & $.76^{\star}(.24)$ & $.70^{\star}(.25)$ \\
Court realignment & $-17.82^{\star}(3.99)$ & - & $-26.05^{\star}(3.23)$ & - \\
Court composition $(t)$ & - & $3.37^{\star}(.95)$ & - & $5.31^{\star}(.71)$ \\
Constant & $37.88(33.82)$ & $20.77(37.80)$ & $-17.44(29.78)$ & $-34.29(29.66)$ \\
AR(1) & $.08(.18)$ & $.29(.16)$ & $.03(.21)$ & $.01(.22)$ \\
Ljung-Box Q & 9.99 & 14.20 & 7.11 & 15.53 \\
\hline
\end{tabular}

Note: $N=34$. For replication models, dependent variable is the annual percentage of all case decided in a liberal direction. For alternative models, dependent variable is the annual percentage of all reversals decided in a liberal direction. Court realignment is coded as 0 for the years 1956-70 and as 1 thereafter. Public mood is the public's overall liberalism as measured by the index of aggregated survey items (Stimson 1991). The composition of the Court is the sum of the justices' ideological scores, as measured by Segal and Cover (1989). $\mathrm{AR}(1)$ is the autoregressive parameter. Numbers in parentheses are standard errors; ${ }^{*} \mathrm{p}<.01$.

lower courts, the ideological direction of decisions to affirm will systematically run counter to the known preferences of the justices and the ideological content of the policies or rules adopted in decisions. By including such cases in their analysis, scholars thus run the risk of introducing an "affirmance bias" that can adversely affect their conclusions.

We have also presented an empirical evaluation of the aggregate outputs of the Court and of the individual voting behavior of justices that provides strong support for our argument. Importantly, replication of a prominent study of the effects of public opinion and judicial preferences on the Court's outputs demonstrates that the consequences of affirmance bias can be severe. Overcoming this evidence would require an alternative, compelling explanation that can account for why a large set of decisions-affirmances-fails so spectacularly as a valid indicator of the Court's policy outputs.

Most statistical analyses of the Court routinely include affirmances in the analysis. Our results suggest that for research that involves the ideological content of Supreme Court output as measured by the ideological direction of the Court's decisionseither as a dependent or an independent variabledoing so can be costly. Our results demonstrate, for example, that the impact of the justices' preferences is even greater than the staunchest adherents of the attitudinal model have demonstrated. At the same time, the significant explanatory power of other variables of interest may have long been obscured by the "affirmance bias." To the extent that mixing together reversals and affirmances mutes or confounds analytic results-and we have offered substantial evidence that it will-the answers to many research questions are likely to be affected: Is the Court constrained by the ideological composition of the elected branches? Does the voting behavior of individual justices change over time? What impact do the Court's policies have on litigants, lower courts, and interest groups? How do the Court's policies affect public opinion, and vice versa? Revisiting even "settled" questions by excluding affirmances from the analysis may yield new and surprising answers to these questions. At first glance, a prescription to focus analysis only on decisions to reverse may seem counterintuitive. Yet by improving the gauge of judicial behavior, doing so is likely to throw any number of issues into greater relief.

\section{Acknowledgments}

The debts we incurred in writing this article are substantial. The greatest thanks go to James Stimson and Mike MacKuen for their extended and insightful discussions of this research. At various points, we have also benefited from the insights of John Aldrich, Barry Friedman, Virginia Gray, Anna Harvey, David Lowery, Stuart Macdonald, Thomas Oatley, George Rabinowitz, Harold Spaeth, and Terry Sullivan. We are also grateful to the anonymous reviewers, especially Reviewer 5.

\section{Appendix}

Quantitative analyses of Supreme Court decision making often account for the preferences of the justices, and the typical strategy is to model the impact of the Court's absolute preferences. The argument we present focuses instead on the Supreme Court's preferences, relative to the Courts of Appeals. This strategy may seem unique, but in fact any 
Alternative Models of Annual Liberalism on Supreme Court, 1953-2004

\begin{tabular}{|c|c|c|c|c|c|}
\hline \multirow[b]{2}{*}{ Variable } & \multirow{2}{*}{$\begin{array}{c}\text { All Cases } \\
(1)\end{array}$} & \multicolumn{2}{|c|}{ Reversals Only } & \multicolumn{2}{|c|}{ Affirmances Only } \\
\hline & & $\begin{array}{c}\text { All reversals } \\
\text { (2) }\end{array}$ & $\begin{array}{c}\text { Conflict excluded } \\
\text { (3) }\end{array}$ & $\begin{array}{c}\text { All affirmances } \\
(4)\end{array}$ & $\begin{array}{c}\text { Conflict excluded } \\
(5)\end{array}$ \\
\hline $\begin{array}{l}\text { Supreme Court } \\
\text { Preferences }\end{array}$ & $.45^{\star}(.07)$ & $.60^{\star}(.12)$ & $.77^{\star}(.13)$ & $-.18^{\star}(.08)$ & $-.34^{\star}(.12)$ \\
\hline Dynamics $\left(\mathrm{Y}_{\mathrm{t}-1}\right)$ & $-.04(.13)$ & $.21(.14)$ & $.10(.14)$ & $.07(.14)$ & $.09(.14)$ \\
\hline Constant & $.33(.05)$ & $.15(.04)$ & $.12(.04)$ & $.52(.09)$ & $.58(.10)$ \\
\hline R-Squared & .63 & .75 & .73 & .11 & .21 \\
\hline
\end{tabular}

Note: $N=51$. Dependent variable is annual percentage of cases decided in a liberal direction. The Supreme Court Preferences are measured as the median Segal-Cover (1989) ideology score. Numbers in parentheses are standard errors; ${ }^{*} \mathrm{p}<.05$.

statistical model that assesses the impact of the Court's preferences employs (at least implicitly) the Court's relative preferences. For example, to code the Court's ideology as "conservative" in an absolute sense is only meaningful if, in other cases in the model, the Court's ideology takes on values to the left of that position. In other words, what makes a natural Court conservative is that it is conservative relative to some other natural Court whose ideology is somewhere to the left of its present position. So, while most statistical models measure the Court's ideology with respect to time- "How conservative is the Court this term compared to last term?"-we model the Court's ideology with respect to other courts- "How conservative is the Court compared to the Courts of Appeals?"

Our measurement strategy is driven by the need to operationalize our theory. But our results are hardly dependent upon our measure of preferences. Barring massive and rapid attrition in the lower courts, replacement on the Court is likely to move the Court to the left or right relative to both its prior ideology and the ideology of the lower courts. For example, President Bush's successive appointments of Chief Justice Roberts and Justice Alito-fully 22\% of the Court-were not accompanied by a $22 \%$ turnover in the Courts of Appeals, and this had the effect of moving the Court's preferences to the right, relative to both the current Courts of Appeals and the Supreme Court's previous ideology.

As an alternative strategy, we could have used an absolute measure of the Court's preferences and specified, simply by assumption, that any ideological change in the Court from one term to the next moves the Court away from the preferences of the mass of lower court judges. To illustrate this, we provide below the same models that appear in Table 1 . The only difference is that, instead of employing the Supreme Court's ideology compared to the lower courts' ideology, we measure the Supreme Court's preference as measured by the median Segal-Cover (1989) ideological score. (We could also employ the Martin-Quinn dynamic ideal points and again produce similar results. Since these scores are based upon votes, however, some might be concerned about possible circularity problems.) Aside from the expected differences in the coefficients between the models, the results are stable and produce the same inferences as those derived from Table 1.

Manuscript submitted 19 September 2007

Manuscript accepted for publication 9 December 2008

\section{References}

Baum, Lawrence. 1988. "Measuring Policy Change in the U.S. Supreme Court." American Political Science Review 82 (3): 905-12.

Boucher, Robert L., and Jeffrey A. Segal. 1995. "Supreme Court Justices as Strategic Decision Makers: Aggressive Grants and Defensive Denials on the Vinson Court." Journal of Politics 57 (3): 824-37.

Caldeira, Gregory A., and John R. Wright. 1988. "Organized Interests and Agenda Setting in the U.S. Supreme Court." American Political Science Review 82 (4): 1109-27.

Caldeira, Gregory A., John R. Wright, and Christopher J. W. Zorn. 1999. "Sophisticated Voting and Gate-Keeping in the Supreme Court." Journal of Law, Economics, and Organization 15 (3): 549-72.

Cameron, Charles, Jeffrey Segal, and Donald Songer. 2000. "Strategic Auditing in a Political Hierarchy: An Informational Model of the Supreme Court's Certiorari Decisions." American Political Science Review 94 (1): 101-16.

Carrubba, Clifford J., Barry Friedman, Andrew Martin, and Georg Vanberg. 2008. "Does the Median Justice Control the Content of Supreme Court Opinions?" Presented at the Yale University Political Economy Workshop, New Haven, CT.

Collins, Paul M. 2004. "Friends of the Court: Examining the Influence of Amicus Curiae Participation in U.S. Supreme Court Litigation." Law and Society Review 38 (4): 807-32.

Epstein, Lee, and Jack Knight. 1998. The Choices Justices Make. Washington, DC: CQ Press. 
Eskridge, William N. 1991. "Overriding Supreme Court Statutory Interpretation Decisions." Yale Law Journal 101 (2): 331-456.

Harvey, Anna. 2006. "What Makes a Judgment 'Liberal'? Measurement Error in the United States Supreme Court Judicial Database." Typescript. New York University.

Klein, David E., and Robert Hume. 2003. "Fear of Reversal as an Explanation of Lower Court Compliance." Law and Society Review 37 (3): 579-606.

Lax, Jeffrey R., and Charles M. Cameron. 2007. "Bargaining and Opinion Assignment on the U.S. Supreme Court." Journal of Law, Economics, and Organization 23 (2): 276-302.

Maltzman, Forrest, James F. Spriggs II, and Paul J. Wahlbeck. 2000. Crafting Law on the Supreme Court: The Collegial Game. New York: Cambridge University Press.

Martin, Andrew D., and Kevin M. Quinn. 2002. "Dynamic Ideal Point Estimation via Markov Chain Monte Carlo for the U.S. Supreme Court, 1953-1999.” Political Analysis 10 (2): 134-53.

McGuire, Kevin T., and James A. Stimson. 2004. "The Least Dangerous Branch Revisited: New Evidence on Supreme Court Responsiveness to Public Preferences." Journal of Politics 66 (4): 1018-35.

Mishler, William, and Reginald S. Sheehan. 1993. "The Supreme Court as a Countermajoritarian Institution? The Impact of Public Opinion on Supreme Court Decisions." American Political Science Review 87 (1): 87-101.

Norpoth, Helmut, and Jeffrey A. Segal. 1994. "Comment: Popular Influence on Supreme Court Decisions." American Political Science Review 88 (3): 711-16.

Perry, H. W., Jr. 1991. Deciding to Decide: Agenda Setting on the United States Supreme Court. Cambridge, MA: Harvard University Press.

Rehnquist, William H. 1987. The Supreme Court: How It Was, How It Is. New York: William Morrow.

Richards, Mark J., and Herbert M. Kritzer. 2002. "Jurisprudential Regimes in Supreme Court Decision Making." American Political Science Review 96 (2): 305-20.

Rohde, David W., and Harold J. Spaeth. 1976. Supreme Court Decision Making. San Francisco: W.H. Freeman.

Schubert, Glendon. 1965. The Judicial Mind: The Attitudes and Ideologies of Supreme Court Justice, 1946-1963. Evanston, IL: Northwestern University.
Segal, Jeffrey A., and Albert D. Cover. 1989. "Ideological Values and the Votes of U.S. Supreme Court Justices." American Political Science Review 83 (2): 557-65.

Segal, Jeffrey A., and Harold J. Spaeth. 2002. The Supreme Court and the Attitudinal Model Revisited. New York: Cambridge University Press.

Songer, Donald R., Charles M. Cameron, and Jeffrey A. Segal. 1995. "An Empirical Test of the Rational-Actor Theory of Litigation." Journal of Politics 57 (4): 1119-29.

Spaeth, Harold J. 2006. "The Original United States Supreme Court Judicial Database, 1953-2005 Terms.” East Lansing, MI: Michigan State University.

Stearns, Maxwell. 2002. Constitutional Process: A Social Choice Analysis of Supreme Court Decision-Making. Ann Arbor: University of Michigan Press.

Stimson, James A. 1991. Public Opinion in America: Moods, Cycles, and Swings. Boulder, Co: Westview Press.

Ulmer, S. Sidney. 1984. "The Supreme Court's Certiorari Decisions: Conflict as a Predictive Variable." American Political Science Review 78 (4): 901-11.

Whittington, Keith E. 2005. "Interpose Your Friendly Hand: Political Supports for the Exercise of Judicial Review by the United States Supreme Court." American Political Science Review 99 (4): 583-96.

Kevin T. McGuire is professor of political science, University of North Carolina at Chapel Hill, Chapel Hill, NC 27599.

Georg Vanberg is associate professor of political science, University of North Carolina at Chapel Hill, Chapel Hill, NC 27599.

Charles E. Smith, Jr., is associate professor of political science, University of Mississippi, University, Mississippi 38677.

Gregory A. Caldeira is Distinguished University professor of political science, Ohio State University, Columbus, Ohio 43210. 